\title{
Preliminary survey of the mosses (Bryophyta) from Los Glaciares National Park, Santa Cruz Province, Argentina
}

\author{
Celina M. MATTERI ${ }^{1}$ \& María M. SCHIAVONE ${ }^{2}$
}

${ }^{1}$ CONICEry, Museo Argentino de Ciencias Naturales "Bernardino Rivadavia", Av. A. Gallardo 470, C1405DJR Buenos Aires, Argentina. matteri@macn.gov.ar. ${ }^{2}$ UNT, Fundación Miguel Lillo, M. Lillo 205, 4000 Tucumán, Argentina.saca@csnat.unt.edu.ar

\begin{abstract}
The main moss communities from Los Glaciares National Park, province of Santa Cruz, Argentina, occurring in various types of vascular vegetation, are described. The survey included different cold temperate Nothofagus forest types to the west, evergreen, summergreen, and mixed forests, and the shrub steppe to the east. An aiphabetical list of the studied species, as well as representative specimens and notes on habitat and subtrata, are presented. Among the material collected, 111 species and two varieties were recognized, 42 of which are new records for the provinoe of Santa Cruz.
\end{abstract}

Key words: Mosses, Bryophyta, Los Glaciares, Santa Cruz, Argentina.

A comprehensive moss collection, as well as detailed field observations on distribution and composition of the moss communities were carried out by the authors during three summer seasons, 1987/88/90, within the limits of National Park Los Glaciares (Fig. 1). Survey included different cold temperate Nothofagus forest types and the shrub steppe. The Park is situated in the southwest of Santa Cruz province, and extends over ca. 600,000 hectares. It was created in 1937 , and it also contains a World Heritage Site since 1981.

In southern Patagonia, Santa Cruz moss vegetation is virtually unknown perhaps with the sole exception of the lands between $51^{\circ}-52^{\circ} \mathrm{S}$ latitude, which were explored by the authors on previous projects (Matteri, 1985, 1986). Historically, only three moss species among Per Dusén's collections fall within this Park (Dusên, 1906), whereas Carl Skottsberg collected a dozen moss species strictly North of the region (Cardot \& Brotherus, 1923). The important contribution of mosses to the forest vegetation in the area has been reported by several botanists, nonbryologists, such as Skottsberg (1916, 1921), Pérez Moreau $(1959,1962)$ and Pisano \& Dimitri (1973), including the incidental mention of some common mosses.

The aim of this study is to provide a preliminary floristic assessment of the moss flora of the area surveyed. Still, a number of moss collections remain unidentified and a complete systematic report will be presented elsewhere. Nevertheless, a general account can be anticipated of the major moss habitats recognised so far at the vegetation types referred to above, as well as information on the role played by different moss communities in different habitats.

\section{THE LAND}

The area currently studied lies in the southwestern upper corner of Santa Cruz province, between $50^{\circ}$ and $50^{\circ} 40^{\prime} \mathrm{S}$ latitude, within the well known Continental Ice Region (Fig. 1). Lago Argentino, a typical Andean lake, running eastward to the Atlantic Ocean through the Santa Cruz River, dominates the landscape. The western end of the lake runs far into the Preandean Mountains by way of two bigger arms, which in turn, open out into countless channels and small fiordlike inlets receiving extensive glaciers from the western Ice Sheets. The investigated forests fall entirely along the western border of National Park Los Glaciares where high rounded mountains attain $2000-2300 \mathrm{~m}$ a.s.l., just East of the main Andean chain.

Due to the broken nature of the terrain Nothofagus trees ("beech") do not form large forested areas but limited thickets in sheltered valleys and flanking glaciers, on gentle slopes from lake level (185 $\mathrm{m}$ a.s.1.) to estimated $1000-1100 \mathrm{~m}$ 


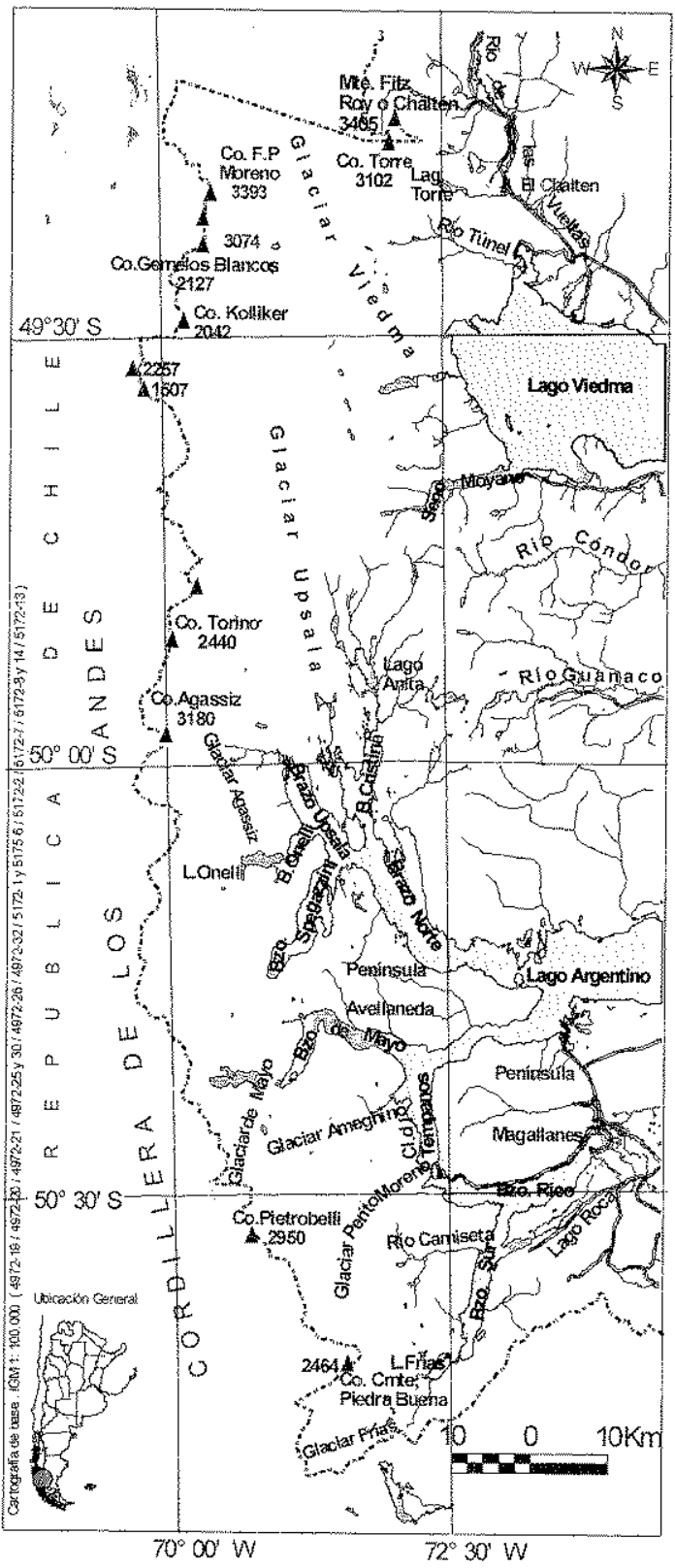

Fig. 1. Map of Parque Nacional Los Glaciares, Santa Cruz Province, Argentina.

a.s.l. (Pérez Moreau, 1959). Inland vegetation is often split by the occurrence of small glacial lakes with ice-blocks adrift, high cliffs with waterfalls, flooded areas, free morraines and swift-running rivulets. The land is wind-swept by dominant western wet winds and the annual rainfall is roughly estimated around $1500-2000 \mathrm{~mm}$ (Pérez Moreau, 1959, Schwerdtfeger, 1976).
Along the eastern limits of the Park, from Mt. Fitz Roy (49-17' S-73ㅇ $05^{\prime} \mathrm{W}$ ) southward, to the vicinity of Glacier Frias (50 $42^{\circ} \mathrm{S}-73^{\circ} \mathrm{W}$ ), scattered and open forest stands give way to the shrub. steppe district. Low mean annual rainfall (200. $300 \mathrm{~mm}$ ) and desiccating winds determine the dryness of soil and impoverishing of the vegetation on this fringe, mostly situated in lowlands, at $200-400 \mathrm{~m}$ a.s.l.

\section{THE VEGETATION}

Despite the presence of the summergreen Nothofagus pumilio ("lenga") forests all over this region, several different forest types can be distinguished mainly when cryptogamic vegetation is being considered. Following most closely the vegetation analysis made by Pisano \& Dimitri (1973), moss fieldwork was centred around stands of pure summergreen $N$. pumilio, evergreen associations of $N$. betuloides ("guindo") with Drimys winteri ("canelo") and on mixed stands of summergreen-evergreen Nothofagus. Forest stands were selected amongst mature undisturbed communities with no evidence of logging or other human activities.

The shrub steppe, on its north-south course, follows approximately $73^{\circ}$ W longitude, and on this ca. $300 \mathrm{~km}$ transect it crosses the western half of both lakes, Viedma on the North, and Argentino on the South. It is mostly characterised by xerophyte vegetation, together with grassy prairies and mesophyte elements from western sectors.

\section{i. Summergreen Forest Moss Communities}

Moss vegetation in pure stands of Nothofagus pumilio have been studied at Bahía Onelli (50\% $08^{\prime} \mathrm{S}, 73^{\circ} 26^{\prime} \mathrm{W}$ ) and at southwestern corner of Península Magallanes (50 $30^{\circ} \mathrm{S}, 73^{\circ} 10^{\prime} \mathrm{W}$ ), just facing Perito Moreno Glacier (Fig. 2).

These forest stands develop from lake level to nearly $600 \mathrm{~m}$ a.s.l., on low-lying areas or gently sloping valleys among glaciers. Trees are well developed but the open canopy determines a most luminous forest with the floor covered with littex among big boulders and few rotten logs. In the shrub layer Maytenus magellanica is a common element together with Berberis buxifolia (Fig. 2) and Myoschilos oblongum. Whereas, Embothrium coccineum is frequent in coastal sites. The forest floor is sparsely covered by Viola maculata, Blechnum penna-marina, Acaena ovalifolia and in marshy areas by Gunnera magellanica and Escallonia virgata (Fig. 3). Empetrum rubrum, in turn, forms continuous bushes on forest floor in 


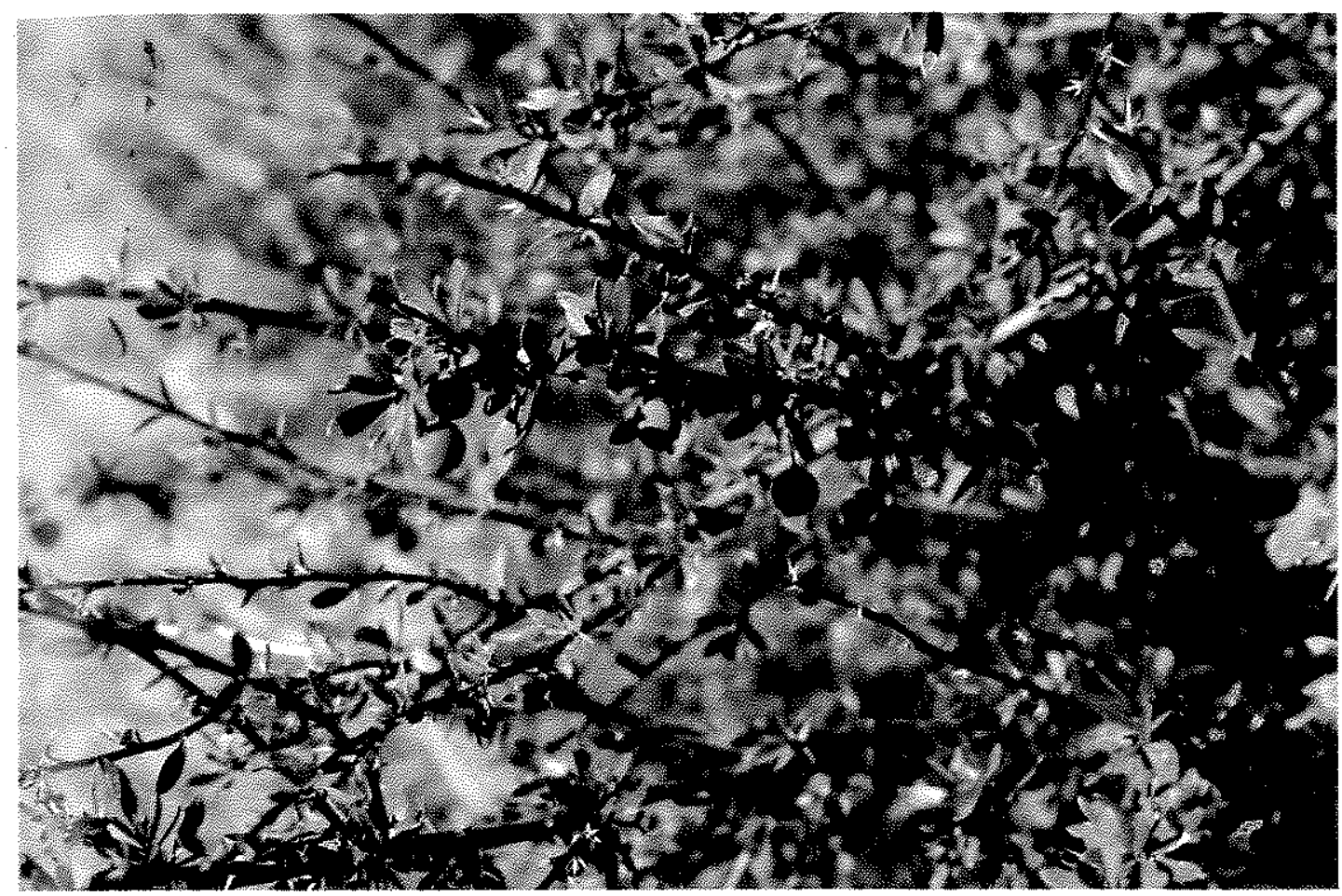

Fig. 2. Berberis buxifolia in fruit.

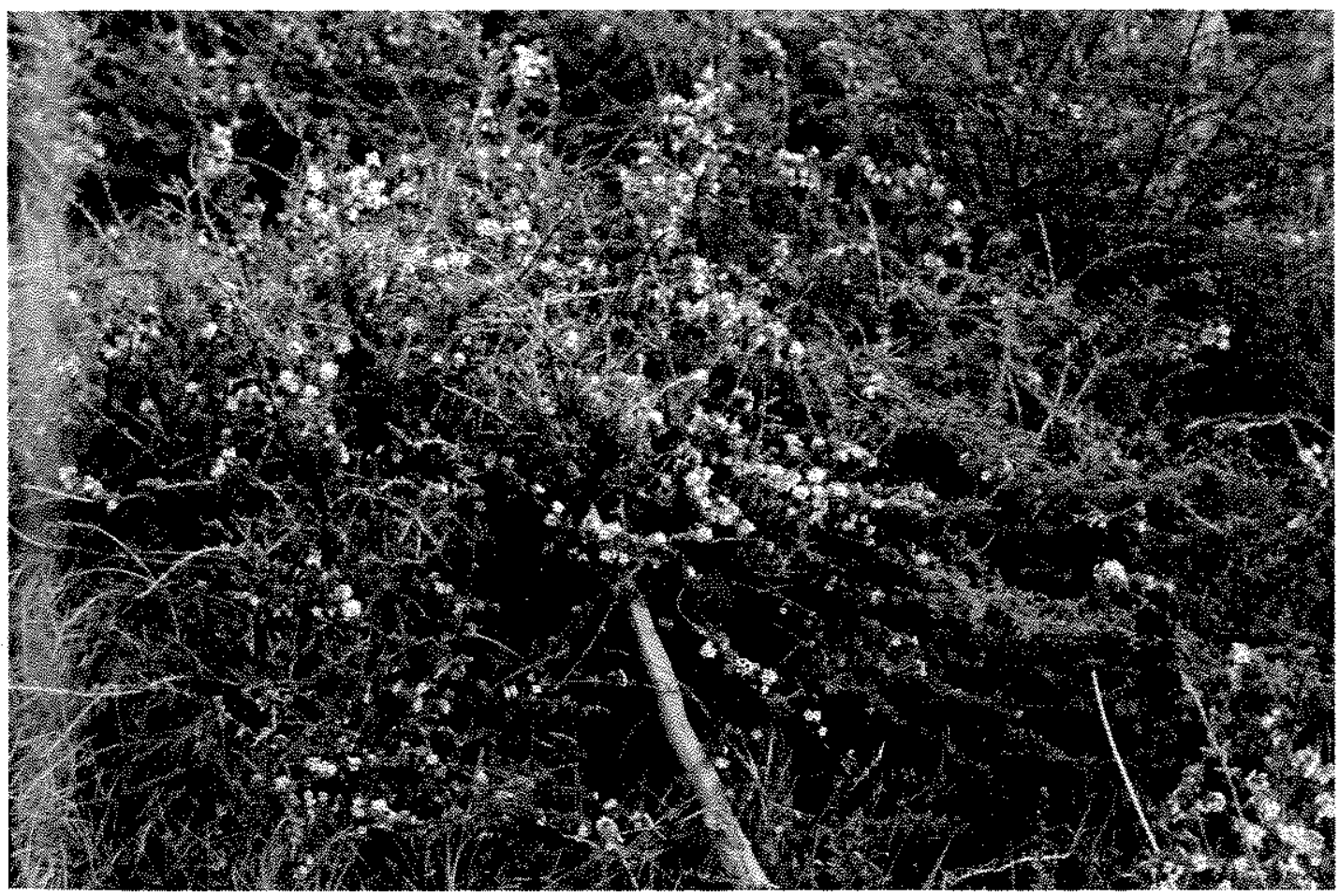

Fig. 3. Escallonia virgata in flower. 


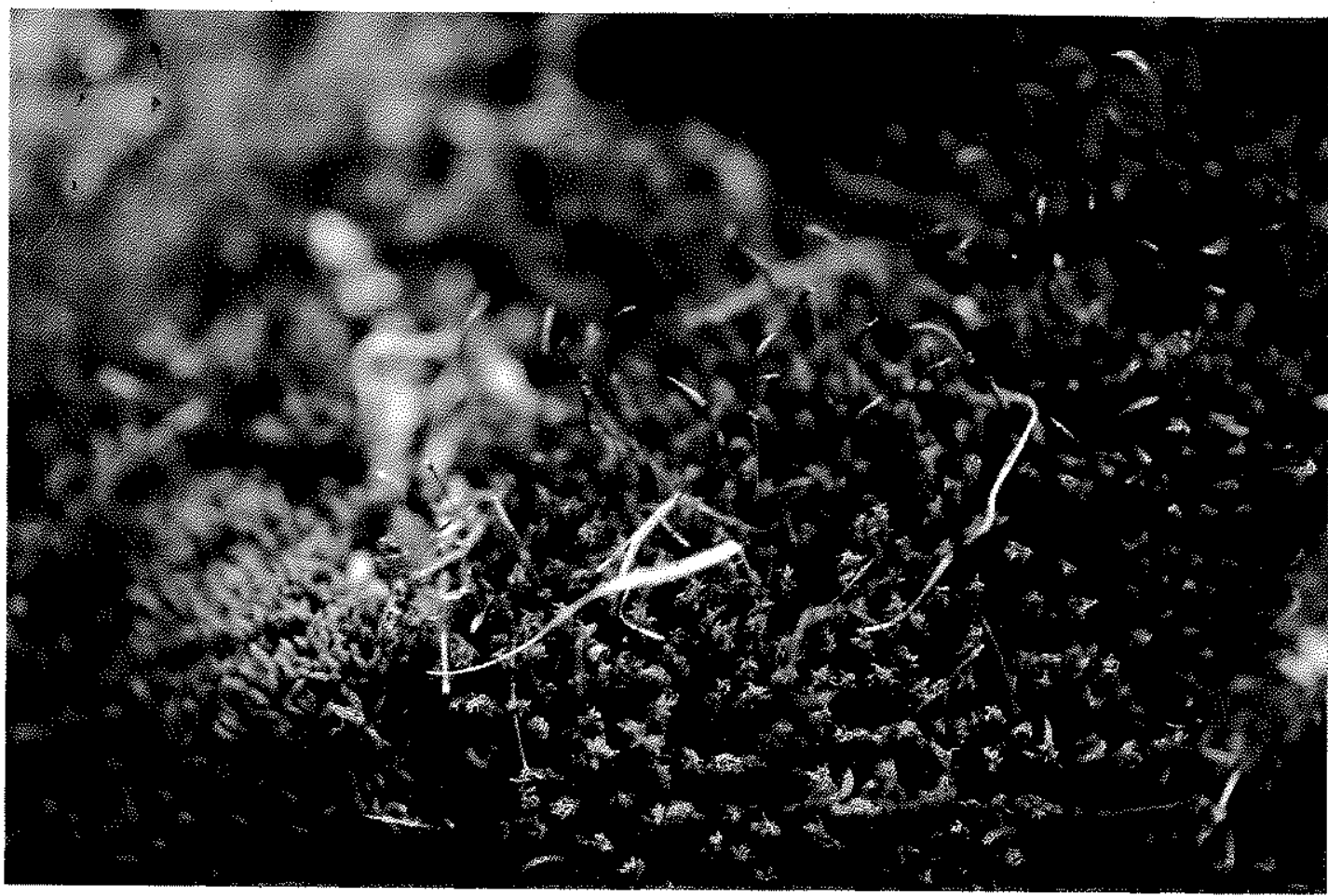

Fig. 4. Syntrichia anderssonii (Ångstr.) R.H.Zander

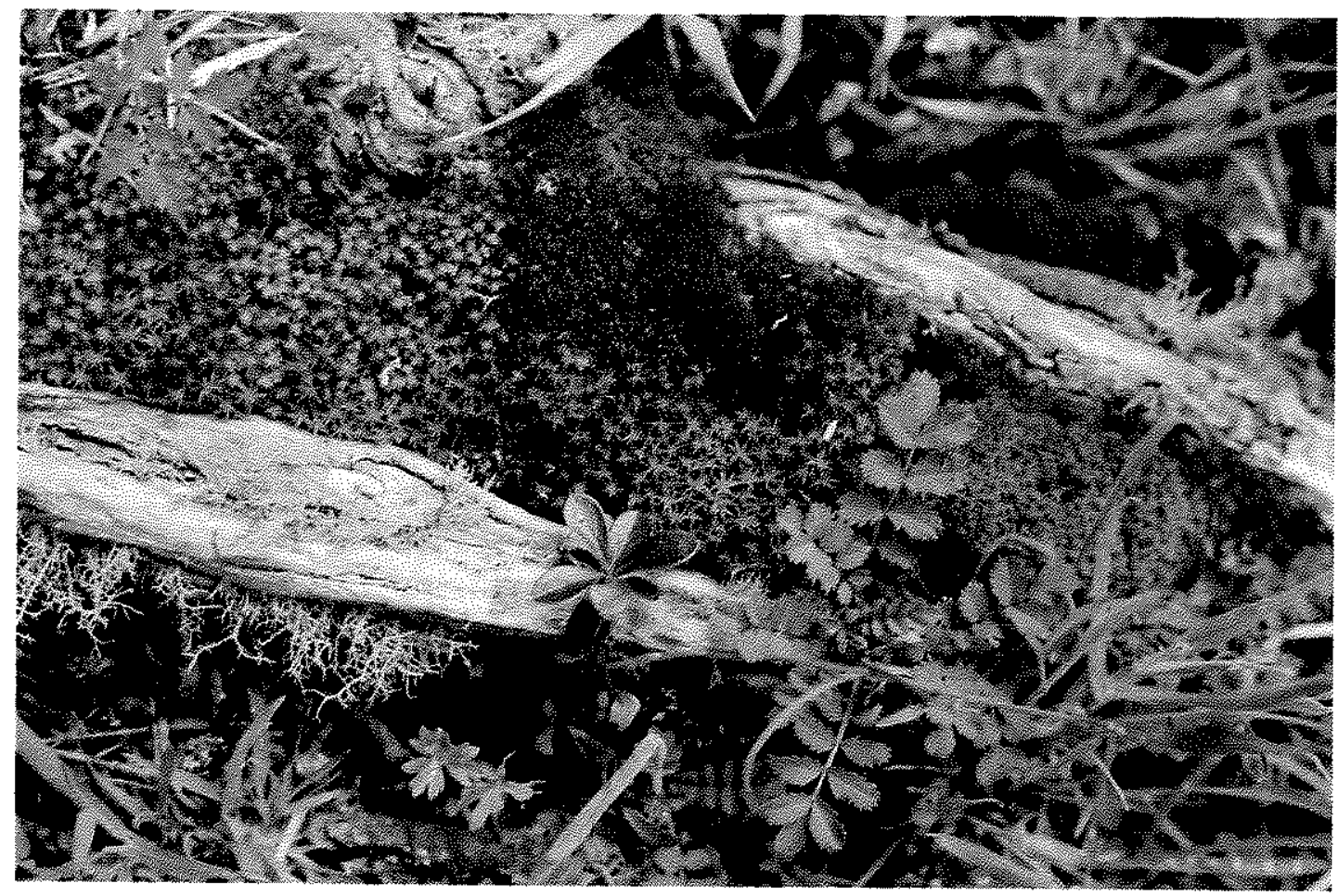

Fig. 5. Rosulabryzm perlimbatum Cardot \& Syntrichia robusta (Hook. \& Grev.) R.H.Zander 
very open sites or along streambanks, usually climbing up around tree bases. Vascular epiphytes s are very rate, except for the parasite Misodenarum

Richest moss habitats in these forests are by far represented by boulders, high cliffs and living tree trunks in this order, with floor communities less abundant. A striking saxicolous moss cover, together with filmy ferns and many lichens, forms at times such a thick carpet over everything that it masks the true nature of the substratum. This feature was particularly observed in forest stands at Bahia Onelli where the hanging moss carpets are usually dripping water. The communities are mainly composed of showy mosses with weft life forms such as Leptodon smithii, Neckera chilensis, Stenomitrium pentastichum and tall turfs of Eustichia longirostris, Bartramia halleriana, $B$. ithyphylla, etc. Hidden and nesting among them, there are smooth mats of the tiny Fabronia ciliaris interwoven with Syntrichia anderssonii (Fig. 4), and short turfs of various species of Encalypta, Philonotis nigroflava, $P$ scabrifolia, Catagonium nitens var. myurum, Plagiothecium ovalifolium and Bartramia patens, among others. Curiously, the giant Leptostomum menziesii believed to be a strict epiphyte, is growing abundantly on scattered boulders and even small colonies could also be found on the floor. Its turfs are often so dense that no other plant grows intermixed.

Vertical walls behind waterfalls show a particularly dense moss layer composed of a few hygrophylous species of the large-cushion life form such as Breutelia integrifolia, Distichophyllum kraussei, Fissidens rigidulus and Eurhynchium fuegianum. A few meters from the main waterspray, tall turfs of Pyrrhobryum mnioides and Entosthodon laxus are plentiful.

Epiphytic moss communities in Nothofagus pumilio forests are also conspicuous on bark of trees and shrubs. Luxuriant bushy rough mats of Lepyrodon lagurus, L. tomentosus, Acrocladium auriculatum, together with abundant tall turfs of fruiting Leptostomum menziesii, small cushions of Ulota spp. and Calyptopogon mnioides carpeted tree trunks to over 1.5-2 m of their length. Rough mats of Brachythecium paradoxum were only present covering tree bases and roots, at times associated with Leptotheca gaudichaudii.

Although considerable litter occurs on the form est floor, moss communities are notably sparse. This forest floor is typically recognised by the presence of two dominant mosses. One is Syntrichia robusta (Fig. 5), a large plant, orange green in colour with an intriguing life form. It grows as an unbroken loose weft, with prostrate and erect stems little attached to the substratum, struggling and intertwining with every other plant or seedling found on its way. The second one is Rosulabryum perlimbatum (Fig. 5), a former rarity, less frequent than the other but equally common. It forms definite rounded and tough communities of the tall-turf life form, thickly matted with tomentum.

Polytrichaceous mosses in this region are less abundant as compared to Fuegian moss vegetation (Matteri \& Schiavone, 1988). However, as ground dwellers they are often found in medium sized colonies on flat forest floor or gentle eroded slopes. In this situation Polytrichum juniperinum and $P$. piliferum (Fig. 6) are common while Polytrichadelphus magellanicus is rarer, all of which form tall hard turfs. Associated with them we find Platyneurum praealtum and rough mats of Brachythecium subpilosum.

In places where the low lying terrain becomes wet and marshy Nothofagus pumilio almost disappears and gives way to scattered stunted and crooked $N$. antarctica, the rustic "nire." However, not strictly a forest habitat these marshes contain a rich hygrophylous moss flora intermixed with Cyperaceae and Gunnera magellanica, Blechum penna-marina and Berberis buxifolia. Here, we find lax tall turfs of the pearl colour Racomitrium lanuginosum (Fig: 7) and the golden Codriophorus laevigatus (Fig. 8) growing at their best, together with Orthotheciella varia on small stumps, Pohlia wahlenbergii, Bryum laevigatum, Dicranella cardotii, and the bushy Breutelia angustiretis (Fig. 10),

\section{ii. Evergreen Forest Moss Communities}

Pure stands of evergreen trees such as those of Southeastern Fuegia or western Magallanes, are infrequent in this region. Some limited stands may be found on western inlets of the central part of Lago Argentino, extending over gentle slopes for $200 \mathrm{~m}$ above the lake level. Well developed copses were investigated mainly at the southern end of Seno Mayo ( $\left.50^{\circ} 22^{\prime} \mathrm{S}, 73^{\circ} 16^{\prime} \mathrm{W}\right)$, just facing Mayo Glacier and to a less extent, in the vicinity of Bahía Canario ( $50^{\circ} 26^{\prime} \mathrm{S}, 73^{\circ} 12^{\prime} \mathrm{W}$ ) on the western shore of Canal de los Témpanos (Fig. 1). The dominating tree is Nothofagus betuloides, associated with Drimys winteri as a lower element. The understory contains as predominant members Pseudopanax laetevirens and Maytenus magellanica. The littoral fringe of this associa. tion shows a thick shrub layer mainly composed of Berberis buxifolia and Pernettya mucronata, often mixed with Escallonia rubra and Fuchsia magellanica. The forest floor is densely littered, with many rotten logs and sparsely distributed 
are Luzuriaga marginata, Blechnum penna-marina and Lebetanthus myrsinites.

Moss communities are sparsely distributed on this shady forest floor, densely on rotten logs, and also up, to $2 \mathrm{~m}$ on living trees. A particularly intexesting moss habitat is represented by clearings in the forest canopy with a thick graminaceous floor layer. In this situation, the most common floor colonies in the forest are of the loose weft life form as in Ptychomnion cygnisetum and of the rounded tall lax turfs such as Dicranoloma robustum, D. hariotii, Goniobryum subbasilare, Platyneurum praealtum, and a couple of species of Tayloria. Extensive patches of the handsome Polytrichastrum longisetum (Fig. 9) grow intermixed with Leptodontium longicaule var. microruncinatum, Breutelia plicata and again, but infrequently, Syntrichia robusta (Fig. 5).

Still solid rotten logs in the forest are colonised by thick carpets of liverworts, lichens and mosses. Among the latter there are short loose wefts of Ptychomnion cygnisetum, a common ground dweller, Ulota spp., Orthodontium lineare, the little and former rarity Sauloma tenella, with rough mats of the weedy Acrocladium auriculatum.

From tree bases upward, to almost $2 \mathrm{~m}$ high, moss colonies are very well developed on living trees. Huge carpets of Lepyrodon lagurus, $L$. tomentosus and Leptostomum menziesii wrap tightly the Nothofagus bark, continuing unbroken into the tree roots with soft mats of Catagonium nitens, rough mats of Sanionia uncinata, thick turfs of Zygodon hookeri and Bartramia halleriana, together with large patches of fruiting Leptotheca gaudichaudii.

\section{iii. Mixed Forest Moss Communities}

An interesting association of evergreen and summergreen Nothofagus forests was surveyed at Bahía Toro $\left(50^{\circ} 17^{\prime} \mathrm{S}, 73^{\circ} 16^{\prime} \mathrm{W}\right)$ on the northernmost corner of Seno Mayo and at the so named Refuge Bay ( $\left.50^{\circ} 24^{\prime} \mathrm{S}, 73^{\circ} 15^{\prime} \mathrm{W}\right) \mathrm{ca} .2 \mathrm{~km} \mathrm{~N}$ of Bahía Ameghino. There, very old Nothofagus betuloides and Drimys winteri thrive associated with equally old $N$. pumilio. They grow at lake level, on a very rugged terrain surrounded by high cliffs with waterfalls and streamlets, creating an adequate shady and extremely wet environment for lower cryptogams.

The understory is also very thick with dominant Maytenus magellanica, Berberis buxifolia (Fig. 2), B. ilicifolia and Ribes magellanicus. While the herbaceous layer is predominantly formed by ferns such as Polystichum mohrioides, Cystopteris fragilis, Asplenium dareoides and Blechnum penna-marina, among filmy ferns, and Maytenus disticha, Acaena ovalifolia, Osmorrhyza obtusa and the orchid Codonorchis lessonii.

Under these vascular conditions, mosses are more abundant on the so to speak "floor", because flat open floor is not seen anywhere. Cracked and crumpled soil banks, wet pockets, streambeds and strongly putrid logs and stumps are the dominant moss substrata. Dendroid life forms such as those of Dendroligotrichum dendroides and Hypopterygium didictyon are common ground elements together with tall turfs of the almost weedy Pyrrhobryum mnioides. Clayish wet banks are carpeted by loose tall turfs of Bartramiapatens, B. halleriana, Goniobryum subbasilare, Polytrichadelphus magellanicus, Notoligotrichum minimum, and large wefts of Ptychomnion cygnisetum. Bartramia ithyphylla, Dendroligotrichum squamosum and Philonotis scabrifolia are present on low vertical drier banks.

Stones and stumps partially submerged in streambeds are colonised by open turfs of Breutelia plicata, Philonotis vagans and soft mats of the rarer Sauloma tenella, Calyptrochaeta apiculata and Achrophyllum magellanicum. Vittia pachyloma is plenty in fruit submerged in these streams.

The lower one metre of tree trunks are loosely covered by rough mats of the common Lepyrodon lagurus and $L$. tomentosus, to which might be added lax wefts of Lembophyllum orbiculatum, Rigodium adpressum and R. brachypodium. From tree bases to the green ground cover there are soft mats of Catagonium nitens, C. nitens var. myurum, Hypnum skottsbergii and Brachythecium paradoxum. Whereas, in definite rounded turfs on the ground we find the coprophilous Tayloria magellanica, T. mirabilis and T. dubyi.

Also in these forest stands the waterfall spray zone offers many rock pockets, hollows and rock crevices for Breutelia plicata, B. integrifolia, Eurhynchium fuegianum, Philonotis vagans and Cladomniopsis crenato-obtusa, among other strongly hygrophylous moss communities.

\section{iv. Shrub Steppe}

As might be expected, the moss flora of the shrub-steppe is less rich in number of species than farther to the west. Though, mosses together with lichens are the dominant and frequently the only visible green cover of most rock habitats in the district. Watercourses or seepage areas yield also important habitats for moss vegetation. The shrub steppe district lies between the eastern grassy steppe and the western summergreen forests. East and West limits of the transect are in many cases indistinct due to the intrusion of elements from 


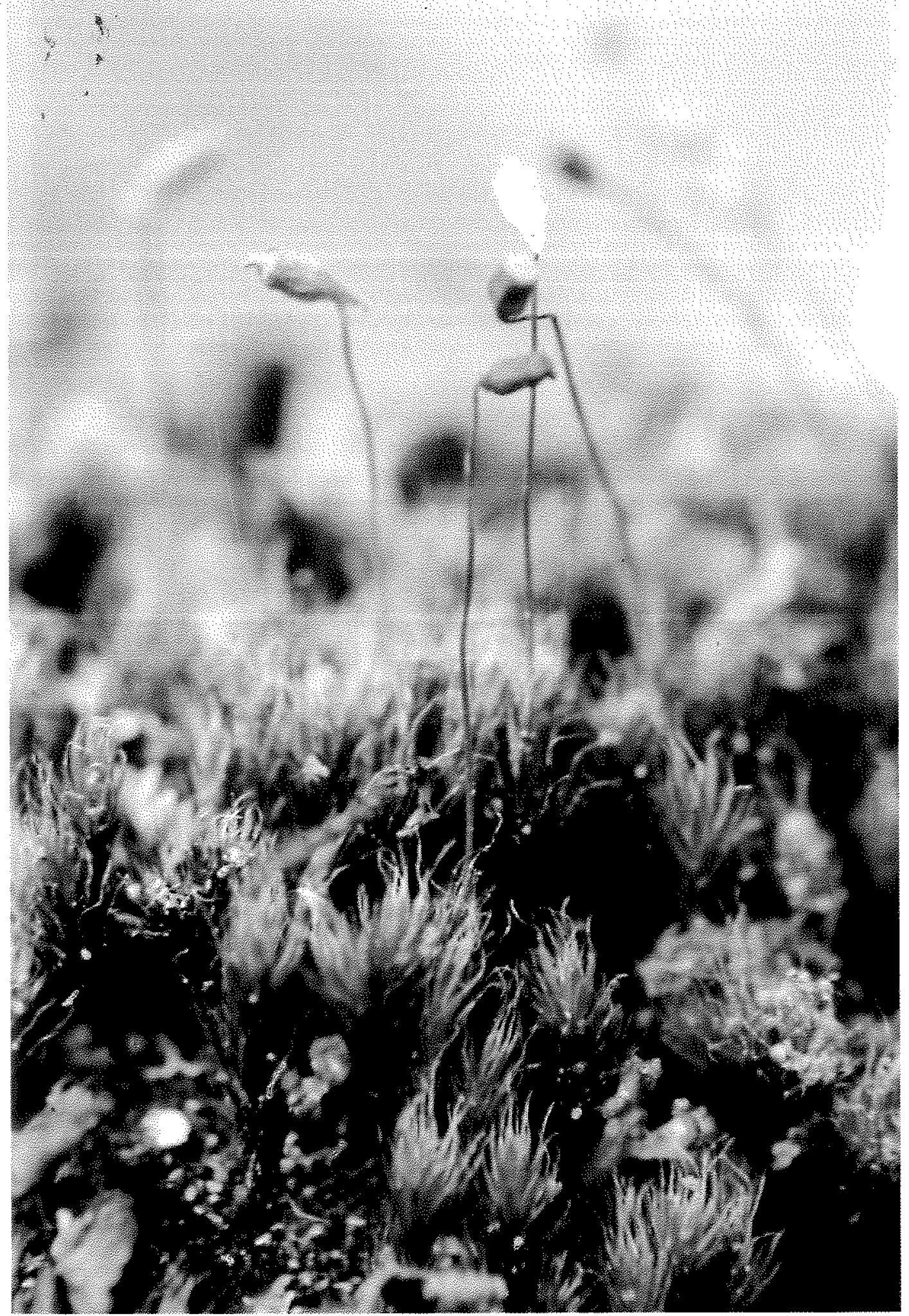

Fig, 6. Polytrichum piliferum Hedw. 


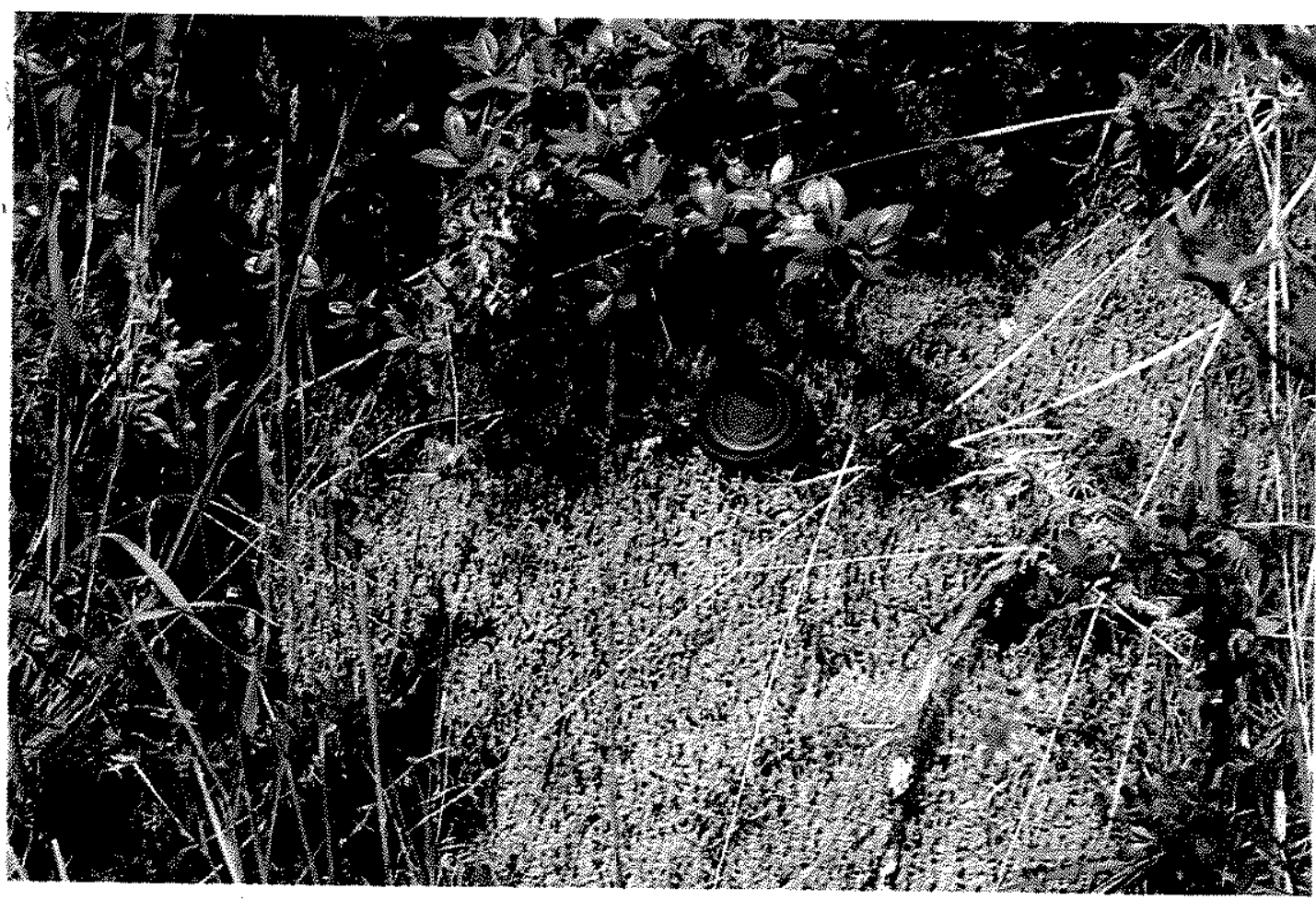

Fig. 7. Racomitrium lanuginosum (Hedw.) Brid.

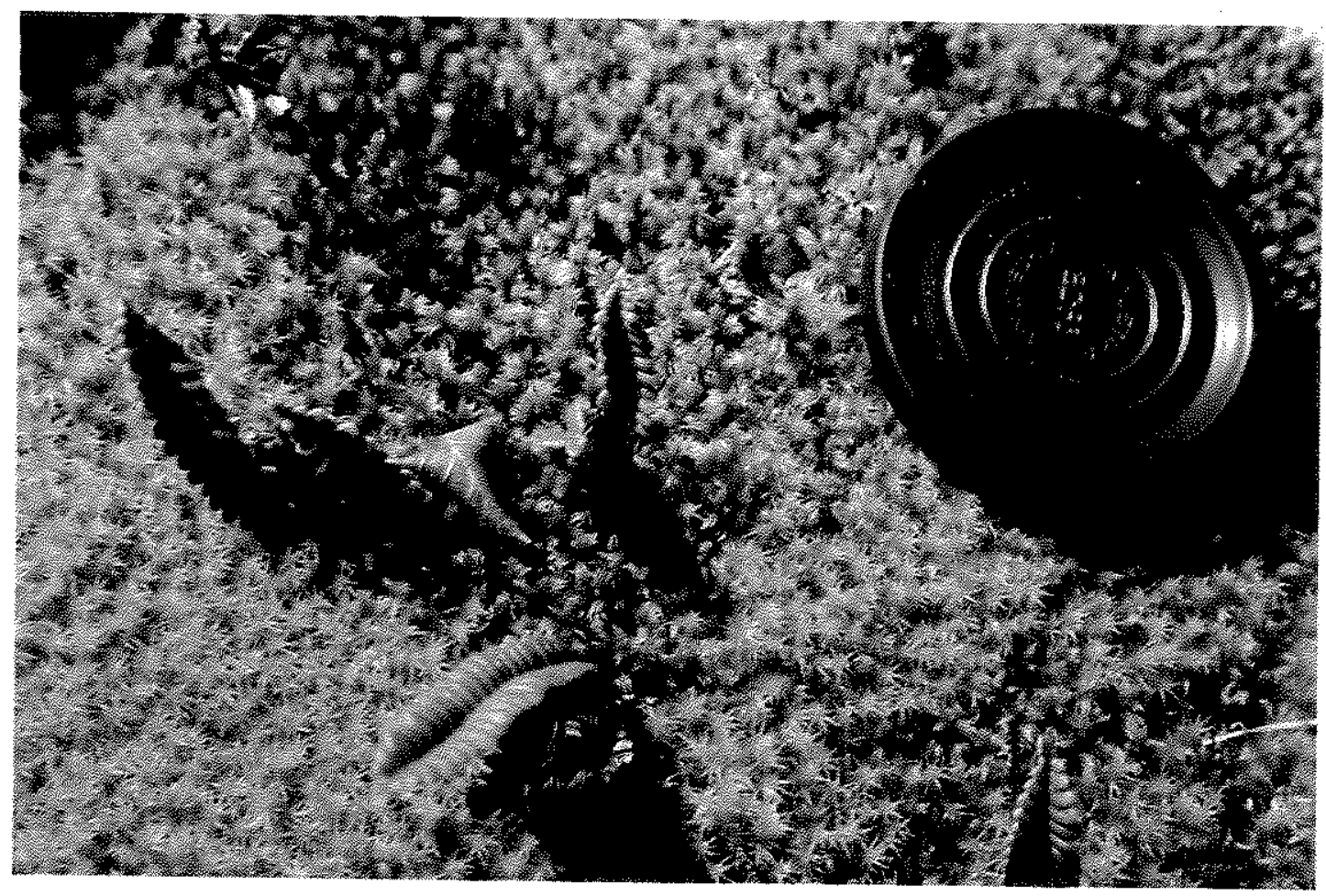

Fig. 8. Codriophorus laevigatus A.Jaeger 
both adjacent districts. Distinctive vegetation of the shrub teppe is characterised by mostly scattered communities of pricking xerophytic and somé mesôphytic vascular elements. Most common shrubs are Mulinum spinosum ("neneo"), Discaria chacaye ("espino blanco"), and the weed Berberis buxifolia ("calafate") (Fig. 2).

Rock banks of temporary or seasonal shallow watercourses create a moister environment for more fragile flowering herbs such as Calceolaria biflora, C. uniflora, Erodium cicutarium, Acaena ovalifolia, Gentianella magellanica or either Osmorrhiza chilensis and various Senecio spp., growing everywhere.

Most mosses on this sector are tiny, dusty and blackish cushions or short turfs. Across the shrubsteppe rock habitats are very common. Hollows, rock crevices, small pockets or irregular slits where some ground and litter retain moisture are good habitats for mosses of the cushion-forming life form. Sarconeurum glaciale, a Pottiaceae formerly a Fuegian-Antarctic endemic, is plenty and fruiting. Northernmost plants were found around Chaltén population $\left(49^{\circ} 20^{\prime} \mathrm{S}\right)$. Together with it, cushions of $2-3 \mathrm{~cm}$ wide of Schistidium apocarpum, Weissia patagonica, the weed Ceratodon purpureus, reddish Bryoerytrophyllum recurvirostre, and Psudocrossidium crinitum, Didymodon ampliretis, and stunted turfs of Bartramia stricta are similarly frequent.

The genus Encalypta, with two species, is equally common, fully in fruit all along the transect as a rock or ground dweller.

Exposed rocky surfaces across the shrubsteppe more often than not, are fully covered by big Polytrichaceae, Polytrichum juniperinum and P. piliferum (Fig. 6). The latter is the most frequent Polytrichaceae of desiccated habitats in Patagonia. They thrive intermixed with Hennediella densifolia, Bartramia patens and Platyneurum praealturn.

Wetter rock banks found along streams or small rivulets on western limits of the shrub-steppe rendered interesting bryological results. In between stones and on gravelly soil at water level, large populations of Philonotis nigroflava, Dicranella hookeri and Pohlia wahlenbergii are abundant.

Narrow courses of melting waters descending from gentle sloping grounds into the flat shrubsteppe spread moisture superficially, forming seepage areas, shallow lagoons and "vegas". Amongst the cyperaceous vegetation of these areas, xerophytic mosses give way to more mesic communities. Impressive golden lax turfs of the rare Aulacomnium palustre (Fig. 11) are abundant. When observed closely, they reveal the presence of masses of brown propagulae. Sporophytes of this widespread species are not known on this part of the world (Matteri, 1988). In between the Aulacomnium turfs, marshy areas are occupied by other interesting species not found elsewhere in the shrub-steppe, such as Plagiomnium ellipticum, Campylium polygamum, and Bryum laevigatum.

The occurrence of slow running rivulets with earth-banks fringed by grasses, crumpled trees, bushes and Escallonia virgata (Fig. 3) are not uncommon in the shrub-steppe. There, one can find huge colonies of almost subaquatic mosses of the oper wefts type such as the bright yellow Brachythecium subpilosum, fruiting Orthotheciella varia, Drepanocladus longifolius and Pohlia wahlenbergii.

\section{THE MOSSES}

This is an alphabetical list of the mosses so far identified within the boundaries of National Park Los Glaciares. We recognized 74 genera, 111 species and 2 varieties among which there are 42 new records for the province of Santa Cruz (*), Two ad. ditions recently made by Müller (2002) from within the Park are also included. Several of these new records fill in the former gap between north Patagonia and the Fuegian region, east to the Andes, e.g. Leptotheca gaudichaudii, Calyptrochaeta odontoloma, Breutelia plicata, B. subplicata, Notoligotrichum minimum, Tayloria dubyi, $T$. mirabilis, etc.

Afew others, such as Rosulabryum macrophyllum, Blindia magellanica, Entosthodon laxus, Goniobryum subbasilare, and Dicranella cardotii, extend their range from the Fuegian region northward, into southern Patagonia. Summing up all these additions, the actual figure of mosses recorded from Santa Cruz provinee is raised from 132 taxa (Matteri, 2003) to 174 taxa. Additionally, if we include Racomitrium patagonicum Bednarek-Ochyra \& Ochyra, a new species recorded from just North of the Park (BednarekOchyra \& Ochyra, 2003), the actual figure for Santa Cruz is 175 taxa. Original collections are deposited in BA, and most of them have been distributed as series I of Musci Patagonici Exiccati to CHR, KRAM, $\mathrm{MO}$ and S. The list includes voucher specimens and data on substrata.

\section{Achrophyllum magellanicum (Besch.) Matteri \\ Vouchers: CM 5084, 5568 (BA). \\ Substr. Stream-banks.}

Acrocladium auriculatum (Mont.) Mitt.

Vouchers: CM 4871, 4900a (BA).

Substr. Rotten logs and bark. 
Amphidium lapponicum (Hedw.) Schimp.

Vouchers: Müiller, F., C1340 (DR, cf. Müller 2002).

(chubstr. On rockface.

Aulacomnium palustre (Hedw.) Schwägr. Vouchers: CM 4839, 5314, 5485, 5467, 5485 (BA).

'Substr. In marshy ground and "vegas".

Bartramia halleriana Hedw.

Vouchers: CM 4638, 4954, 4959, 5030, 5098, 5461 (BA).

Substr. On tree roots and earth-banks.

Bartramia ithyphylla Brid.

Vouchers: CM 4523, 4999, 5091 (BA).

Substr. On wet or dry rocks.

Bartramia patens Brid.

Vouchers: CM 4870, 4940, 5138 (BA).

Substr. On earth-banks and wet or dry soil.

Bartramia stricta Brid.

Vouchers: CM 4535, 5449, 5517b (BA).

Substr. In rock slits on boulders.

* Blindia magellanica Müll.Hal.

Vouchers: CM 4952 (BA).

Substr. Under waterfall on rocks.

Brachythecium austroglareosum (Müll.Hal.) Kindb.

Vouchers: CM 4872, (BA).

Substr. On boulders.

Brachythecium paradoxum (Hook.f. \& Wilson) A.Jaeger

Vouchers: CM 4867, 5104, 5135 (BA).

Substr. On tree roots.

Brachythecium subpilosum (Hook.f. \& Wilson) A.Jaeger

Vouchers: CM 4492, 5491 (BA).

Substr. On forest floor.

Brachythecium subplicatum (Hampe) A.Jaeger

Vouchers: CM 4792, 5137 (BA).

Substr, On earth-banks.

Breutelia angustiretis E.B.Bartram

Vouchers: CM 4953, 5050 (BA).

Substr. In marshy ground and under cascades.

Breutelia integrifolia (Taylor) A.Jaeger Vouchers: CM 4964, 4966, 5086, 5117 (BA).

Substr. Stream-banks under water-spray.

* Breutelia plicata Mitt.

Vouchers: CM 4987, 5022 (BA).

Substr. Wet rockfaces.

* Breutelia subplicata Broth.

Vouchers: CM 4902 (BA).

Substr. Forest floor.
Bryoerytrophyllum recurvirostre (Hedw.) P.C.Chen

Vouchers: CM 5575 (BA).

Substr. On rocks slits.

Bryum laevigatum Hook.f. \& Wilson

Vouchers: CM 4975, 5024, 5434, 5489, 5537 (BA).

Substr. Stream-banks and marshy ground.

Bryum pseudotriquetrum (Hedw.) P.Gaertn., B.Mey. \& Scherb.

Vouchers: CM 4982, 5025, 5074, 5132 (BA).

Substr. Littoral banks, stream-banks, among stones.

* Bucklandiella striatipila (Cardot) Bednarek-Ochyra \& Ochyra

Vouchers: CM 4902 (BA).

Substr. In graminaceous forest floor.

* Calyptrochaeta odontoloma (Matteri) Matteri

Vouchers: CM 4969 (BA).

Substr. On stumps in stream.

Campylium polygamum (Schimp) Lange \& C.E.O.Jensen.

Vouchers: CM. 4851, 5487 (BA).

Substr. In marshy ground.

* Campylopus introflexus (Hedw.) Brid.

Vouchers: CM 4894, (BA).

Substr. Forest floor.

* Catagonium nitens (Brid.) Cardot

Vouchers: CM 4928, 5041 (BA).

Substr. Dry bedrocks and banks.

* Catagonium nitens var. myurum (Cardot \& Thér.) S.H.Lin

Vouchers: CM 4929 (BA).

Substr. On banks.

Ceratodon purpureus (Hedw.) Brid.

Vouchers: CM 4994, 5039, 5547 (BA).

Substr. On ground and dry bedrock.

Chorisodontium dicranellatum (Dusén) Roiv.

Vouchers: CM 4791 (BA).

Substr. Among rocks in forest floor.

Chrysoblastella chilensis (Mont.) Reimers

Vouchers: CM 5047 (BA).

Substr: On earth bank.

Cladomniopsis crenato-obtusa M.Fleisch.

Vouchers: CM 4950 (BA).

Substr. On rocks under water-spray.

Codriophorus laevigatus (A.Jaeger)

Bednarek-Ochyra \& Ochyra

Vouchers: CM 4890, 5053 (BA). 


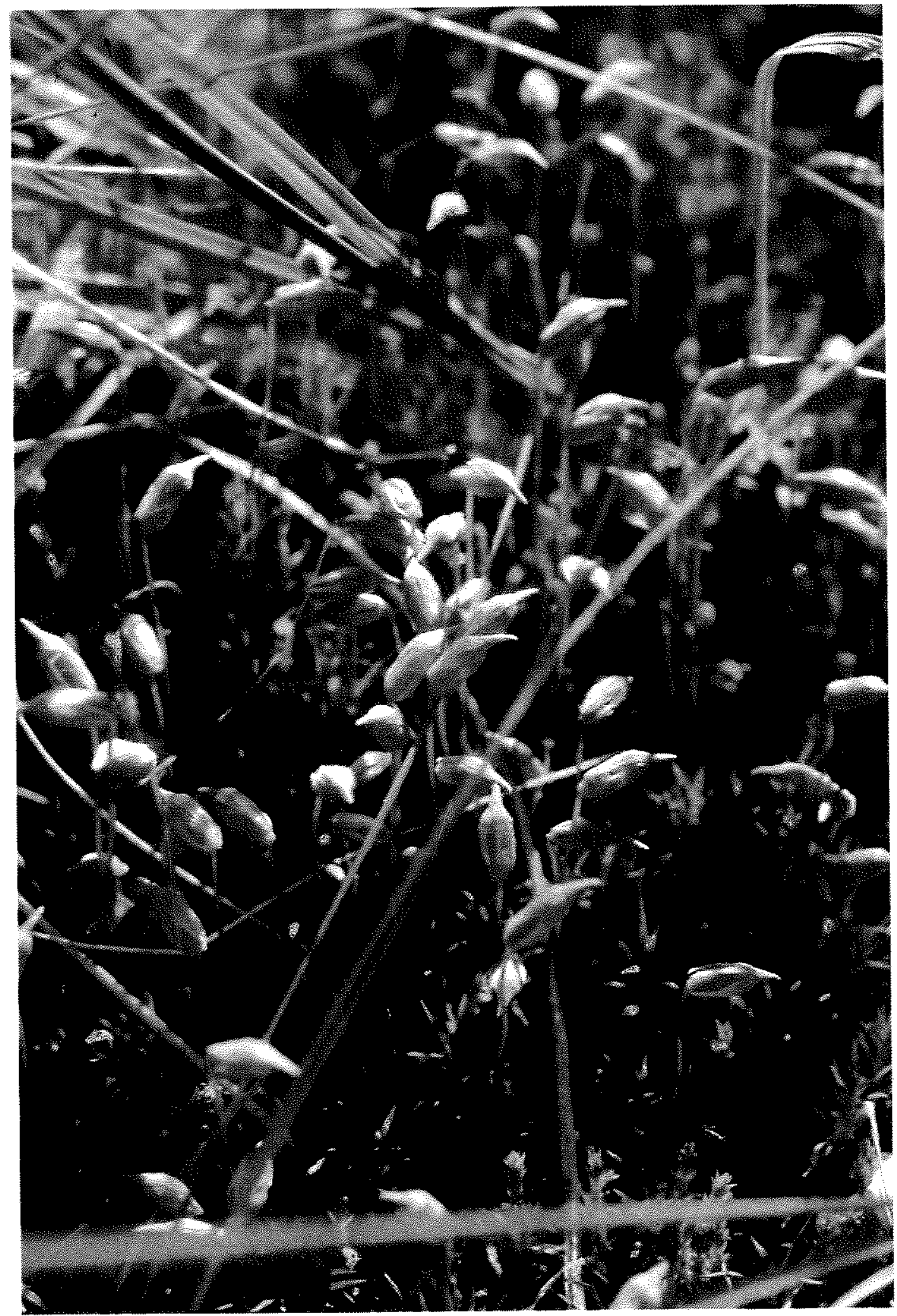

Fig. 9. Polytrichastrum longisetum (Brid.) G.L.Sm. 


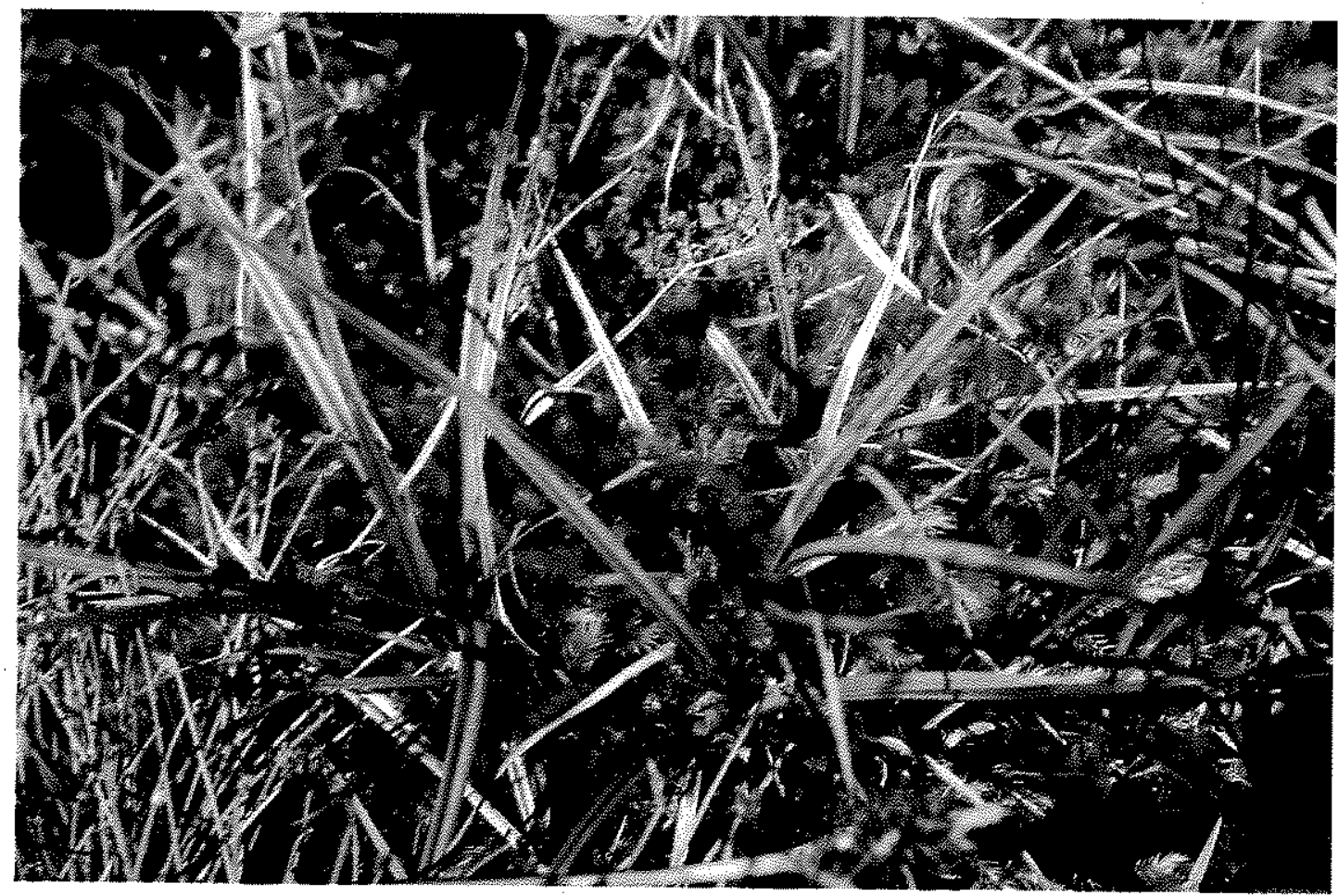

Fig. 10. Breutelia angustiretis E.B.Bartram

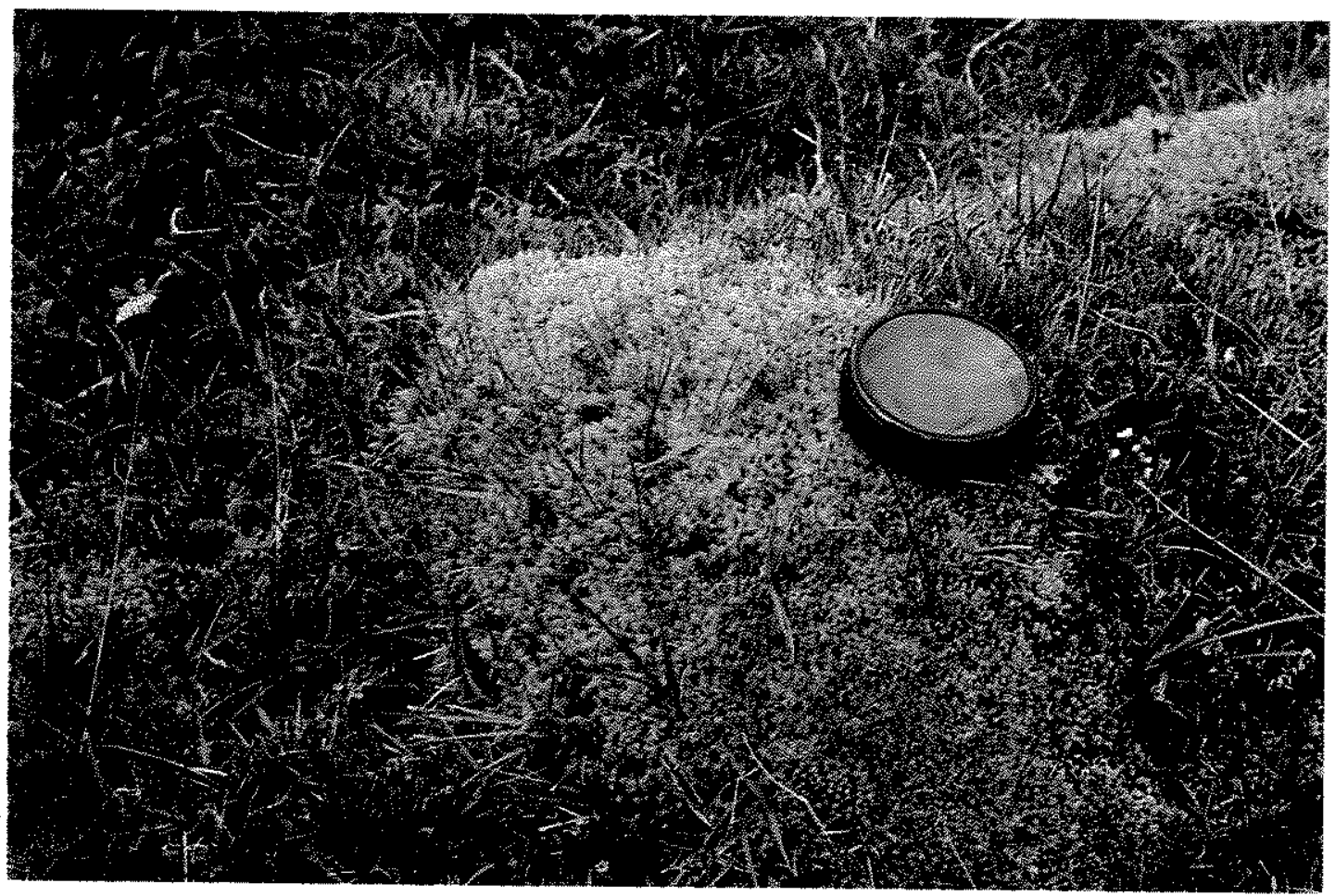

Fig. 11. Aulacomnium palustre (Hedw.) Schwägr. 
Substr. On wet forest floor.

Dendroligotrichum dendroides (Hedw.)

Broth.

Vouchers: 'CM 4938 (BA).

Substr: Dark forest floor.

Dendroligotrichum squamosum (Hook.f. \&

Wilson) Cardot

Vouchers: CM 5006 (BA).

Substr. On litter on boulders.

* Dicranella cardotii (R.Br.bis) Dixon

Vouchers: CM 4506, 4973 (BA).

Substr. In marshy ground and stream-banks.

Dicranella hookeri (Müll.Hal.) Cardot

Vouchers: CM 5131, 5535 (BA).

Substr. In marshy ground and among rocks.

* Dicranoloma hariotii (Müll.Hal.) Paris

Vouchers: CM 4904 (BA).

Substr. On forest floor.

* Dicranoloma robustum (Hook.f. \& Wilson) Paris

Vouchers: CM 4899 (BA).

Substr. Forest floor.

Didymodon ampliretis E.B.Bartram

Vouchers: CM 5556 (BA).

Substr. On rocks in stream-bank

* Didymodon vinealis (Brid.) R.H.Zander Vouchers: CM $5517 \mathrm{c}$ (BA).

Substr. On dry rock slits.

Distichium capillaceum (Hedw.) Bruch \& Schimp.

Vouchers: CM 4845, 5088 (BA).

Substr. On boulders under water-spray.

* Distichophyllum kraussei (Lorentz) Mitt. Vouchers: CM 5116, 5453 (BA).

Substr. On rocks under waterfall.

Drepanocladus longifolius (Mitt.) Paris

Vouchers: CM 4861, 4967, 5368, 5539, 5569 (BA).

Substr. On wet streammbank.

Encalypta ciliata Hedw.

Vouchers: CM 4468, 4534, 4549, 4993, 5123, 5404,5559 (BA).

Substr. On wet rocks and soil.

Encalypta obtusata Cardot \& Broth.

Vouchers: CM 5474, 5506, 5516 (BA).

Substr. On rock slits in stream-banks.

* Entosthodon laxus (Hook. f. \& Wilsor) Mitt. Vouchers: CM 5458 (BA).

Substr. On rocks, under cascade.
Eurhynchium fuegianum Cardot

Vouchers: CM 4757, 4758, 5443, 5560 (BA).

Substr. Rock streambanks, partially submerged.

* Eustichia longirostris (Brid.) Brid.

Vouchers: CM 4518, 5087, 5402, 5457 (BA).

Substr. On wet boulders, under cascade.

Fabronia ciliaris (Brid.) Brid.

Vouchers: CM 4529, 5102, 5414 (BA).

Substr. On wet cliffs.

* Fissidens adianthoides Hedw.

Vouchers: CM 4986 (BA). (cf. Matteri \&

Schiavone 2004)

Substr: On wet rocks.

* Fissidens curvatus Hornsch.

Vouchers: CM 4937, 5028 (BA).

Substr. On dry bedrock.

Fissidens rigidulus Hook.f. \& Wilson

Vouchers: CM 4844, 5115a, 5369, 5562 (BA),

Substr. On rocks under waterfall.

* Funaria hygrometrica Hedw.

Vouchers: CM 5451 (BA).

Substr. Among stones.

* Goniobryum subbasilare (Hook.) Lindb.

Vouchers: CM 4906, 4941 (BA).

Substr. On forest floor.

Hennediella densifolia (Hook.f. \& Wils.)

R.H.Zander

Vouchers: CM 4503 (BA).

Substr. On marshy ground.

Hypnum skottsbergii Ando

Vouchers: CM 4981, 5447 (BA).

Substr. On tree roots and bark.

Hypopterygium didictyon Müll.Hal.

Vouchers: CM 5375 (BA).

Substr. On stream-banks.

\section{* Lembophyllum orbiculatum (Thér.)}

Tangney

Vouchers: CM 4924, 4979 (BA).

Substr. On bark of trees.

* Leptobryum pyriforme (Hedw.) Wilson

Vouchers: CM 5504 (BA).

Substr. On stream-banks.

Leptodon smithii (Hedw.) F.Weber \& D.Mohr Vouchers: CM 4515, 5386 (BA).

Substr. On wet cliffs.

* Leptodontium longicaule Mitt. var. microruncinatum (Dusén) R.H.Zander

Vouchers: CM 4895 (BA). (cf. Matteri 2004b).

Substr. On grassy forest floor. 
Leptostomum menziesii $\mathrm{R}$.Br. bis

Vouchers: CM 4875, 4917, 5124. (BA).

Substr. On bark, rotten logs and rocks.

* Leptotheca gaudichaudii Schwägr.

Vouchers: CM 4909, 5085, 5136, 5392, 5459 (BA).

Substr. On tree roots.

* Lepyrodon hexastichus (Müll.Hal.) Wijk \& Margad.

Vouchers: CM 5126 (BA).

Substr. On bark of trees.

Lepyrodon lagurus (Hook.) Mitt.

Vouchers: CM 4498, 4525, 4920, 4927, 5066, 5409,5429 (BA).

Substr. On bark and rocks.

* Lepyrodon tomentosus (Hook.) Mitt.

Vouchers: CM 4816, 4919, 4926, 5004, 5125, 5381 (BA).

Substr. On bark of trees.

Limprichtia revolvens (Sw.) Loeske

Vouchers: CM 4855, 5119 (BA).

Substr. Sub-aquatic, under cascade.

* Neckera chilensis Mont.

Vouchers: CM 5129, 5415 (BA).

Substr. On rocks.

* Notoligotrichum minimum (Cardot) G.L.Sm.

Vouchers: CM 4933 (BA).

Substr. On clayish bank.

Orthodontium lineare Schwägr.

Vouchers: CM 4901, 5496 (BA).

Substr. On strongly rotten logs.

* Orthotheciella varia (Hedw.) Ochyra

Vouchers: CM 4504, 4772, 4848, 4851, 5042, $5078,5128,5373,5437,5536$ (BA).

Substr. On stones and stumps under water-spray,

Philonotis nigroflava Müll.Hal.

Vouchers: CM 5081, 5093, 5490 (BA).

Substr. Stream-banks and "vegas".

Philonotis scabrifolia (Hook.f. \& Wilson) Braithw.

Vouchers: CM 4552, 4570, 4864, 4997, 5037, $5075,5092,5130,5351,5552$ (BA).

Substr. On stones or forest floor.

Philonotis vagans (Hook.f. \& Wilson) Mitt.

Vouchers: CM 4860, 4949, 4976, 5016, 5374, 5565 (BA).

Substr. Stream-banks, among stones in stream, under water-spray.

Plagiomnium ellipticum (Brid.) T.J.Kop.

Vouchers: CM 5486, 5505 (BA).

Substr. In marshy ground.
Plagiothecium ovalifolium Cardot

Vouchers: CM 4532, 5097 (BA).

Substr. On wet cliffs.

Platyneurum praealtum (Mitt.) Ochyra \& Bednarek-Ochyra

Vouchers: CM 4548, 4790 (BA).

Substr. Forest floor.

Pohlia cruda (Hedw.) Lindb.

Vouchers: CM 4865, 5077, 5110, 5142, 5352 (BA).

Substr. Road banks, stream-banks and dry boulders.

Pohlia drummondii (Müll.Hal.) A.L.Andrews Vouchers: Müller, F., C1493, C1534, C1476 (DR, cf. Müller 2002),

Substr. On wet soil.

* Pohlia nutans (Hedw.) Lindb.

Vouchers: CM 5316 (BA).

Substr. Marshy soil.

* Pohlia wahlenbergii (F.Weber \& D.Mohr) Andrews

Vouchers: CM 5315, 5492 (BA).

Substr. Stream-bank.

Polytrichadelphus magellanicus (Hedw.) Mitt.

Vouchers: CM 4908, 4936, 5005, 5035, 5112, 5146,5456 (BA).

Substr. On wet banks among stones.

Polytrichastrum alpinum (Hedw.) G.L.Sm. Vouchers: CM 5464b (BA).

Substr. On wet soil.

Polytrichastrum longisetum (Brid.) G.L.Sm. Vouchers: CM 4891 (BA).

Substr. In graminaceous soil.

Polytrichum juniperinum Hedw.

Vouchers: CM 4449, 4582, 4803, 4836a 4862, $4988 \mathrm{a}, 4989,5036,5114,5850,5417,5432$, $5464,5493,5545,5577$ (BA).

Substr. On wet or dry soil and on boulders.

Polytrichum juniperinum var. affine

(Funck) Brid.

Vouchers: CM 4565, 4836b (BA).

Substr. On soil.

Polytrichum piliferum Hedw.

Vouchers: CM 4457, 4583, 4804, 4825a, 4835, $4863,5034,5113,5145,5349,5401,5431$, $5465,5507,5524,5546,5578$ (BA).

Substr. On dry ground and rocks.

\section{* Pseudocrossidium crinitum (Schultz) R.H.Zander}

Vouchers: CM 4527b, 4555 (BA).

Substr. In rock crevices. 
* Ptychomnion cygnisetum (Müll.Hal.) Kindb.

Vouchers: CM 4907, 4922, 4931 (BA).

Substr. On rotten logs or forest floor.

* Pyrrhobryum mnioides (Hook.) Manuel Vouchers: CM 4955, 4943, 5027, 5029 (BA).

Substr. Forest floor.

*Racomitrium lanuginosum (Hedw.) Brid. Vouchers: CM 5052, 5390 (BA).

Substr. Among rocks in forest floor.

Rigodium adpressum Zomlefer

Vouchers: CM 4516, 4985, 5010, 6158 (BA).

Substr. On wet littoral rocks.

Rigodium brachypodium (Müll.Hal.) Paris Vouchers: CM 4925, 6159 (BA).

Substr. On bark of trees.

Rigodium pseudo-thuidium Dusén

Vouchers: CM 6160 (BA).

Substr: On forest floor.

Rosulabryum billardierei (Schwägr.) J.R.Spence

Vouchers: CM 5038 (BA).

Substr: On dry bedrock.

* Rosulabryum macrophyllum (Cardot \& Broth.) Ochyra

Vouchers: CM 5353, 5394, 5430, 5570 (BA).

Substr. Wet forest floor.

* Rosulabryum perlimbatum (Cardot) Ochyra

Vouchers: CM 4490, 4887, 5060 (BA).

Substr. Exposed forest floor.

* Sanionia uncinata (Hedw.) Loeske

Vouchers: CM 4770, 4903, 4916, 5014, 5063, $5065,5445,5494$ (BA).

Substr. On tree roots, forest floor, stream-banks, partially submerged.

Sarconeurum glaciale (Müll.Hal.) Cardot \& Bryhn

Vouchers: CM 5515, 5530, 5531 (BA).

Substr. On shrubs, and rock crevices.

* Sauloma tenella (Hook.f. \& Wilson) Mitt. Vouchers: CM 4921, 4970 (BA).

Substr. On wet stumps under water-spray.

* Stenomitrium pentastichum (Mont.) Broth.

Vouchers: CM 5103, 5133, 5403 (BA).

Substr. On wet boulders.

Syntrichia anderssonii (Ångstr.) R.H.Zander

Vouchers: CM 4450, 4463, 4489, 4528, 4556b, $4587 \mathrm{a}, 4590,4830 \mathrm{a}, 4868,5054 \mathrm{a}$ (BA).
Substr. In marshy forest floor, on rocks and boulders, on rotten logs.

Syntrichia papillosa (Wilson) Jur.

Vouchers: CM 5532b (BA).

Substr: On bark of bushes.

Syntrichia princeps (De Not.) Mitt.

Vouchers: CM 5469 (BA).

Substr. On grassy ground.

Syntrichia robusta (Hook. \& Grev.)

R.H.Zander

Vouchers: CM 4483, 4556a, 4896, 5054b, 5460

(BA).

Substr. In forest marshy floor.

* Tayloria dubyi Broth.

Vouchers: CM 4485b, 4944, 5056, 5419 (BA).

Substr. On soil.

Tayloria magellanica (Brid.) Mitt.

Vouchers: CM 4485a, 4914, 4947a, 5421 (BA).

Substr. Open forest floor.

* Tayloria mirabilis (Cardot) Broth.

Vouchers: CM 4486, 4547, 4913, 4945, 5057, $5359,5420,5462$ (BA).

Substr. Open forest floor.

Tayloria stenophysata (Herzog) A.K.Kop. Vouchers: CM 4947b, 5058 (BA).

Substr. Open forest floor.

* Vittia pachyloma (Mont.) Ochyra

Vouchers: CM 4766, 4846, 4946, 5372, 5444, 5514,5561 (BA).

Substr. On wet rocks under water-spray.

Warnstorfia exannulata (Schimp.) Loeske Vouchers: CM 4840 (BA).

Substr. In marshy open ground.

Weissia patagonica Cardot \& Broth.

Vouchers: CM 5517a (BA).

Substr. In rock slits.

*Zygodon hookeri Hampe

Vouchers: CM 4910, 4520 (BA) (cf. Matteri 2004a)

Substr: On wet rocks and tree roots.

Zygodon pichinchensis (Taylor) Mitt.

Vouchers: CM 4519, 4778, 5425 (BA).

Substr. On wet rocks and soil.

\section{ACKNOWLEDGEMENTS}

Authors wish to acknowledge the staff and authorities of the local base of Administracion de Parques Nacionales, the Museo de la Patagonia and Gendarmería Nacional in Calafate who 
worked beyond measure to provide facilities during explorations. Staff officers of the central Administración de Parques Nacionales, P. Cichero and M. Izquierdo, helped in the design of the map in figure 1. The National Geographic Society is also thanked for granting part of fieldwork along National Park Los Glaciares. The generous reviewers are greatly acknowledged for providing their criticism and useful suggestions.

\section{BIBLIOGRAPHY}

Bednarek-Ochyra, H. \& R. Ochyra, 2003. Racomitrium patagonicum, a new moss species from southern South America. Journal of Bryology 25: 181-187.

Cardot, J. \& V. F. Brotherus, 1923. Les mousses. Bihang til Kungliga Svenska Vetenskapsakademiens Handlingar 63 (10): 1-73.

Dusén, P. 1906. Beiträge zur Bryologie der Magellansländer, yon Westpatagonien und Südchile. Teil IV. Arkiv för Botonik 6 (1-2): 1-32.

Matteri, C. M. 1985. Catálogo de los musgos. In Boelcke, O., D.M. Moore \& F.A. Roig (eds.). Transecta Botánica de la Patagonia Austral, 11.2: 265-298, CONICET, Buenos Aires.

Matteri, C. M. 1986. Overview on the phytogeography of the moss flora from Southern Patagonia at $51^{\circ}$ $52^{\circ}$ South Latitude. Journal of the Hattori Botanical Laboratory 60: 171-174.

Matteri, C. M. 1988. Distribution maps of mosses from Tierra del Fuego, Argentina. 1. Lindbergia 14: 176178.

Matteri, C. M. 2003. Los musgos (Bryophyta) de Argentina. Tropical Bryology 24: 33m100.

Matteri, C. M. 2004a. New national and regional bryophyte records, 9. 10. Zygodon hookeri Hampe. Journal of Bryology (in press).

Matteri, C. M. 2004b. New national and regional bryophyte records. 9. 3. Leptodontium longicaule var. microruncinatum (Dusén) Zander. Journal of Bry. ology (in press).

Matteri, C. M. \& M. M. Schiavone. 1988. Comunidades muscinales del suelo de los bosques de Nothofagus fueguinos. Monografías de la Academia Nacional de Ciencias Exactas, Fisicas y Naturales, $\mathrm{n}^{2} 4$, Simposio sobre Nothofagus, p. $25-36$.

Matteri, C. M. \& M. M. Schiavone. 2004. New national and regional bryophyte records, 9. 1. Fissidens adianthoides Hedw, Journal of Bryology (in press).

Müller, F. 2002. New records and new synonyms for the southern South American moss flora. Nova Hedwigia 74 (3-4): 445-450.

Pérez Moreau, R. A. 1959. Reseña botánica sobre el Lago Argentino. Instituto Nacional del Hielo Continental Patagónico (ed.). Publicación $\mathrm{N}^{\circ} 1$, p. 1-37. Buenos Aires.

Pérez Moreau, R. A. 1962. El Seno De Mayo del Lago Argentino. Contribución a su conocimiento botánico. Instituto Nacional del Hielo Continental Patagónico (ed.) Publicación No 5, p. 1-26. Buenos Aires.

Pisano, E. V. \& M. J. Dimitri. 1973. Estudio ecológico de la Región Continental Sur del área AndinoPatagónica. 1. Contribución a la Fitosociología de comunidades arbóreas, arbustivas y herbáceas al Sur-Este del Ventisquero Moreno, Parque Nacional "Los Glaciares", Santa Cruz, Argentina. Anales del Instituto de la Patagonia 4 (1-3): 208-271.

Schwerdtêeger, W. 1976. Climates of Central and South America. World Survey of Climatology Volume 12. Department of Meteorology University of Wiscon. sin, Madison, Wise. (U.S.A.), 96 pp. Elsevier Scientific Publ. Co. Amsterdam. Oxford. New York.

Skottsberg, C. 1916. Botanical Ergebnisse der Schwedischen Expedition nach Patagonien un dem Feuerlande 1907-1909. V. Die Vegetations. verhältnisse Länge des Cordillera de los Andes S. von $41^{\circ}$ S. Br. K. Svensk. Vet-Akad. Handl. 56(5): 1 366.

Skottsberg, C. 1921. Algunos resultados botánicos obtenidos durante la campana de la comisión sueca en los territorios australes de Chile y Argentina, en los años 1908- 1909 (1). Revista Chilena de Historia Natural 25: 474-494. 